\title{
GERMINATION EFFECT OF DIFFERENT SUBSTRATES ON GRUMIXAMA SEEDS
}

TOMIELIS, Ismael Placido GUILHERME, Denilson Oliveira ${ }^{1}$ BRITO, Vitor Hugo dos Santos MAIA, Janini Tatiane Lima Souza CEREDA, Marney Pascoli ${ }^{2}$

SUMMARY: Grumixameira trees belongs to the Myrtaceae family, members of which have simple leaves, which are generally leaf-opposed, with whole margins, an evergreen color. The Myrtaceae family includes about 140 genera and over 3,000 species. Grumixameira trees are rarely cultivated and its production is normally used in the manufacture of bulk candy, syrup, liqueurs and jams. Because it is rarely cultivated there is virtually no agronomic information about the cultivation of this fruit tree, in particular relating to seedling production and seed germination. The objective of this study was to evaluate grumixama seed germination in two substrates; Tecnomax ${ }^{\circledR}$ (based on pine bark) and washed sand. The seeds were sown in plastic tubes with $110 \mathrm{~cm}^{3}$, filled with the respective substrates. Sixty days after sowing the germination percentage was evaluated. The height, stem diameter and number of leaves were evaluated at 120 days, when the seedlings had an average height of $10 \mathrm{~cm}$. The pine bark substrate provided the best germination and development of quality grumixama seedlings compared to the washed sand.

Keywords: Eugenia brasiliensis Lam.. Myrtaceae. Brazil-cherry. Vegetative growth.

RESUMO: A grumixamaeira pertence à família Myrtaceae, cujos membros têm folhas simples, que são em geral de folhas opostas, com margens inteiras e cor verde. A família Myrtaceae inclui cerca de 140 gêneros e mais de 3.000 espécies. A grumixama raramente é cultivada e sua produção é normalmente utilizada na fabricação de doces em massa, xarope, licores e compotas. Como raramente é cultivada, praticamente não há informações agronômicas sobre o cultivo desta árvore. A produção de mudas está em particular relacionada com a germinação das sementes. O objetivo deste estudo foi avaliar a germinação de sementes grumixama em dois substratos: Tecnomax ${ }^{\circledR}$ (a base de casca de pinus) e areia lavada. A semeadura foi realizada em tubetes de $110 \mathrm{~cm}^{3}$, de polietileno de alta densidade preenchidos com os respectivos substratos. Aos sessenta dias após a semeadura foi avaliada a porcentagem de germinação. A altura, diâmetro do caule e número de folhas foram avaliados aos 120 dias, quando as plântulas tinham altura média de $10 \mathrm{~cm}$. O substrato à base de casca de pinus promoveu a melhor germinação e desenvolvimento das mudas de grumixameira em comparação à areia lavada.

Palavra-Chave: Eugenia brasiliensis Lam.. Myrtaceae. Cereja brasileira. Crescimento vegetativo.

\section{INTRODUÇÃO}

Species belonging to the Myrtaceae family have simple leaves, usually leaf-opposed, with whole margins and an evergreen color; this family includes about 140 genera and over 3,000 species (Barroso et al., 1984; Joly, 1993; Ribeiro, 1999). These species are spread over almost every continent, predominantly in tropical and subtropical regions (MARCHIORI; SOBRAL, 1997). The genus Eugenia, which is a significant representative of this species, has many native species in Brazil with commercial and nutritional value, as well as medicinal properties that can contribute to phytopharmaceutical products (SILVA et al., 2003).

This genus contains the species Eugenia brasiliensis Lam., which is commonly known as grumixameira tree, cumbixaba, ibaporoiti or Brazil-cherry (SUGUINO et al., 2011). It is a species with

\footnotetext{
${ }^{1}$ Universidade Estadual do Norte Fluminenes Darcy Ribeiro

${ }^{2}$ Universidade Católica Dom Bosco
} 
astringent, aromatic bark and leaves, and it possesses anti-rheumatic and diuretic activity. As befits a genus that has many species that are rich in essential oils and tannins, reason why are widely used in folk medicine (PIO CORRÊA (1984; LUNARDI et al., 2001). Flowering in Brazil lasts for one to two weeks in September/October, with the formation of berry-type fruit with two basic: yellow and dark purple/black (PIO CORRÊA; 1984; SUGUINO et al., 2011). The fruit is rarely cultivated and production is usually marketed as bulk candy, syrup, syrup, liqueurs and jams.

Grumixama fruits are small globular drupes with two dark seeds, which are the basic form of propagation. Germination occurs 30 to 60 days after sowing. Despite the high percentage of germination it is insufficient to produce seedlings on a commercial scale. Various treatments have been used to increase germination tax, including thermal treatment (MATHEUS et al., 2009; SUGUINO et al., 2006; LAMARCA et al., 2011). Matheus et al. (2009) evaluated the following heat treatments on the germination of grumixama seeds: seeds immersed in water at $60{ }^{\circ} \mathrm{C}$ for 1,3 and 5 minutes; seeds immersed in water at $70{ }^{\circ} \mathrm{C}$ for 1,3 and 5 minutes; and seeds immersed in water at a temperature of $80{ }^{\circ} \mathrm{C}$ for 1, 3 and 5 minutes. They found no effect compared to the control, which received no treatment.

Seed fractionation is an alternative method that is used to maximize the use of seeds from the genus Eugenia. Silva et al. (2003) reported the feasibility of using fractionation to obtain more than one normal seedling from one seed: the best results were obtained with the longitudinal section. Silva, Bilia e Barbedo (2005) submitted seeds from the species of the Eugenia genus, including grumixameira trees, to fractionation. They kept them to half the original size and observed that in the studied species the seeds fractionated in half, containing at least half of the hilum maintained a high germination capacity and the production of normal seedlings.

The success of plant stands using native species depends on good seedling production, both quantitatively and qualitatively. Among the factors that contribute to this process is the substrate, which greatly influences the development of seedlings. This requires studying the physical and chemical characteristics of the substrate, the species that are planted in it, as well as the cost and availability of the chosen substrate (FONSECA, 2001). An appropriate substrate provides adequate support, as well as the retention of water, oxygen and nutrients; factors that can compromise the architecture of the root system and the nutritional status of plants (CARNEIRO, 1983). SOUZA et al. (2012) tested different mixtures of the following substrates, Plantmax ${ }^{\circledR}$, sawdust, rice husk and coconut fibber in the production of pitangueira trees (Eugenia uniflora L.) and cherry trees (Eugenia involucrata DC.) seedlings. They confirmed that the use of alternative substrates was feasible for the production of seedlings from those species. Suguino et al. (2011) evaluated the effect of the porosity of pine bark substrates in the production of grumixama seedlings and noted that the species showed better development when the total porous space of the substrate was less than $90 \%(\mathrm{v} / \mathrm{v})$.

Considering the importance and the richness of species of the Myrtaceae family, particularly grumixameira trees, this study evaluated the germination behavior of Eugenia brasiliensis, and characterized the production of seedlings in two different types of substrates.

The experiment was conducted in a nursery at São Vicente research center, located on Campo Grande, Brazilian State of Mato Grosso do Sul, defined by the geographic coordinates $20^{\circ} 23^{\prime} 00^{\prime \prime}$ latitude South and 54 36' 00" longitude West, at an altitude of 636 meters, between December 2013 and March 2014.

For the sowing, seeds were collected from healthy plants from the matrices of grumixama trees (Eugenia brasiliensis Lam.) located in the aforementioned research center. The two substrates that were used were processed Tecnomax ${ }^{\circledR}$ (composed of expanded vermiculite, pine bark, ash, coconut fiber, charcoal, manure and poultry bedding) and washed sand. Sowing was performed in high-density 
polyethylene tubes with a volume of $110 \mathrm{~cm}^{3}$, which were filled with the respective substrates. One seed per tube was used, at a depth of approximately $2 \mathrm{~cm}$. During the evaluation period, the substrates were irrigated every day.

The germination percentage was evaluated sixty days after sowing. The height, stem diameter and number of leaves were evaluated at 120 days, when the seedlings had an average height of $10 \mathrm{~cm}$.

SAEG software, version 9.1 (SAEG-UFV, 2007) was used for the data analysis. The germination data were transformed (arc sine $\sqrt{X} / 100$ ) in an attempt to obtain normality; they were then submitted to analysis of variance (ANOVA). The means of the treatments were compared by Tukey's test $(p<0.05)$.

The germination of the grumixama seeds that were grown in the pine bark substrate was $23 \%$ higher than for those grown in washed sand (Table 1). Although germination in the pine bark substrate was much higher than for washed sand, it would not be true to say that germination in the washed sand was low, due to lack of information about the germination of this species.

Table 1. Height, root length, number of leaves, stem diameter and germination in grumixama seeds (Eugenia brasiliensis Lam.) seedlings grown in two substrates.

\begin{tabular}{|c|c|c|c|c|c|}
\hline \multirow[t]{2}{*}{ Substrate: } & Germination & Height & Length of roots & \multirow{2}{*}{$\begin{array}{c}\text { Number of } \\
\text { leaves }\end{array}$} & $\begin{array}{c}\text { Diameter of } \\
\text { stem }\end{array}$ \\
\hline & $\%$ & -------- & --cm------------- & & $\mathrm{mm}$ \\
\hline Tecnomax $\left.^{(}\right)$ & $93 \mathrm{a}$ & $12.04 \mathrm{a}$ & $12.31 \mathrm{a}$ & $7.75 \mathrm{a}$ & $1.09 \mathrm{a}$ \\
\hline Sand & $70 \mathrm{~b}$ & $9.75 \mathrm{~b}$ & $11.00 \mathrm{~b}$ & $5.20 \mathrm{~b}$ & $0.74 \mathrm{~b}$ \\
\hline CV (\%) & 13.54 & 10.53 & 9.40 & 25.7 & 11.64 \\
\hline
\end{tabular}

Averages accompanied by the same letter in the column no statistical difference by Tukey test $(\mathrm{p}<0.05)$.

The height, root length and number of leaves of grumixameira seedlings at 120 days were also greater in the pine bark substrate. In this period, the grumixameira seedlings grown in pine bark substrate were an average of $12.04 \mathrm{~cm}$ in height. This was lower than the height found by Suguino et al. (2011), where in a similar substrate, grumixameira seedlings had an average height of $20.64 \mathrm{~cm} 120$ days after sowing.

The better results for seedlings grown in the pine bark substrate may be associated with the better physical and chemical conditions that this substrate provides compared with sand.

The germination of seeds of Eugenia brasiliensis Lam. and biometric parameters of seedlings grown in substrates Tecnomax ${ }^{\circledR}$ and introduced himself superior to cultivation in washed sand.

Substrate based on pine bark provides better germination and development of quality grumixama seedlings compared with washed sand.

\section{ACKNOWLEDGEMENTS}

The authors are grateful to the CNPq and CAPES for the award of a research scholarship. 


\section{REFERENCES}

BARROSO, G.M. et al. Sistemática de Angiospermas do Brasil. v.2. Viçosa: UFV, 1984.

CARNEIRO, J.G.A. Variações na metodologia de produção de mudas florestais afetam os parâmetros morfofisiológicos que indicam a sua qualidade. Curitiba: FUPEF, 1983. p.1-40. (FUPEF, Série Técnica, n.12).

FONSECA, T.G. Produção de mudas de hortaliças em substratos de diferentes composições com adição de $\mathrm{CO}_{2}$ na água de irrigação. Universidade de São Paulo, Escola Superior de Agricultura Luiz de Queiroz. Piracicaba. 2001. 72 p.

JOLY, A.B. Botânica: introdução à taxonomia vegetal. São Paulo: Companhia Editora Nacional, 1993. $777 \mathrm{p}$.

LAMARCA, E.V.; SILVA, C.V.; BARBEDO, C.J. . Limites térmicos para a germinação em função da origem de sementes de espécies de Eugenia (Myrtaceae) nativas do Brasil. Acta Botanica Brasilica v.25, n.2, p. 293-300, 2011.

LUNARDI, I. et al. Triterpenic acids from Eugenia moraviana. Journal of Brazilian Chemical. v.12, n.2, p.180-183, 2001.

MARCHIORI, J.N.C.; SOBRAL, M. (1997). Dendrologia das angiospermas . Myrtales. SantaMaria: Editora da UFSM. 271 p.

MATHEUS, M.T. et al. Efeitos de tratamentos térmicos na germinação de sementes de grumixama (Eugenia brasiliensis). In: ENCONTRO LATINO AMERICANO DE INICIAÇÃO CIENTÍFICA, 9 e ENCONTRO LATINO AMERICANO DE PÓS-GRADUAÇÃO, 5. Anais... 2009. Universidade do Vale do Paraíba, 620-622.

PIO CORRÊA, M. Dicionário das plantas úteis do Brasil e das exóticas cultivadas. v.1. Brasília: Ministério da Agricultura, Instituto Brasileiro de Desenvolvimento Florestal, 1984. 747p.

RIBEIRO, J.E.L.S. Flora da Reserva Ducke: guia de identificação das plantas vasculares de uma floresta de terra firme na Amazônia Central. Manaus: INPA, 1999. 800p.

SILVA, C.V.; BILIA, D.A.C.; BARBEDO, C.J. 2 Fracionamento e germinação de sementes de Eugenia. Revista Brasileira de Sementes v.27, n.1, p. 86-92, 2005.

SAEG- Sistema para Análises Estatísticas e Genéticas. Universidade Federal de Viçosa SAEG:. Versão 9.1. Viçosa, Fundação Arthur Bernardes. 2007. CD-ROM.

SILVA, C.V. et al. 2003. Fracionamento e germinação de sementes de uvaia (Eugenia pyriformis Cambess. - Myrtaceae). Revista Brasileira de Botânica, v.26, n.2, p.213-221, 2003.

SOUZA, P.L.T. et al. Efeito de diferentes substratos no crescimento de mudas de duas Myrtaceae. In: SALÃO INTERNACIONAL DE ENSINO, PESQUISA E EXTENSÃO, 4:2.Anais... 2012.

SUGUINO, E. et al. Mirtáceas com frutos comestíveis do estado de São Paulo: conhecendo algumas plantas. Piracicaba: ESALQ, Divisão de Biblioteca e Documentação, 2006. 56 p. (Série Produtor Rural, $31)$.

SUGUINO, E. et al. Efeito da porosidade do substrato casca de pínus no desenvolvimento de mudas de grumixameira. Revista Brasileira de Fruticultura. 2001, p.643-648 (volume especial). 